\title{
EDITORIAL
}

\section{THE DIALOGUE DECALOGUE: GROUND RULES FOR INTERRELIGIOUS DIALOGUE}

Dialogue is a conversation on a common subject between two or more persons with differing views, the primary purpose of which is for each participant to learn from the other so that he or she can change and grow. This very definition of dialogue embodies the first commandment of dialogue, as will be expanded below.

In the religious sphere in the past, we came together to discuss with those differing with us, for example, Catholics with Protestants, either to defeat an opponent, or to learn about an opponent so as to deal more effectively with him or her, or at best to negotiate with him or her. If we faced each other at all, it was in confrontation-sometimes more openly polemically, sometimes more subtly so, but always with the ultimate goal of defeating the other, because we were convinced that we alone had the absolute truth.

But that is not what dialogue is. Dialogue is not debate. In dialogue each partner must listen to the other as openly and sympathetically as he or she can in an attempt to understand the other's position as precisely and, as it were, as much from within, as possible. Such an attitude automatically includes the assumption that at any point we might find the partner's position so persuasive that, if we would act with integrity, we would have to change, and change can be disturbing.

We are here, of course, speaking of a specific kind of dialogue, an interreligious dialogue. To have such, it is not sufficient that the dialogue partners discuss a religious subject. Rather, they must come to the dialogue as persons somehow significantly identified with a religious community. If I were neither a Jew nor a Muslim nor a Christian, for example, I could not participate as a "partner" in a JewishChristian-Muslim interreligious dialogue, though I might listen in, ask some questions for information, and make some helpful comments.

It is obvious that interreligious dialogue is something new under the sun. We could not conceive of it, let alone do it in the past. How, then, can we effectively engage in this new thing? The following are some basic ground rules, or "commandments," of interreligious dialogue that must be observed if dialogue is actually to take place. These are not theoretical rules, or commandments given from "on high," but ones that have been learned from hard experience.

FIRST COMMANDMENT: The primary purpose of dialogue is to change and grow in the perception and understanding of reality and then to act accordingly. Minimally, the very fact that I learn that my dialogue partner believes "this" rather than "that" proportionally 
changes my attitude toward her; and a change in my attitude is a significant change in me. We enter into dialogue so that we can learn, change, and grow, not so we can force change on the other, as one hopes to do in debate-a hope which is realized in inverse proportion to the frequency and ferocity with which debate is entered into. On the other hand, because in dialogue each partner comes with the intention of learning and changing herself, one's partner in fact will also change. Thus the alleged goal of debate, and much more, is accomplished far more effectively by dialogue.

SECOND COMMANDMENT: Interreligious dialogue must be a two-sided project - within each religious community and between religious communities. Because of the "corporate" nature of interreligious dialogue, and since the primary goal of dialogue is that each partner learn and change himself, it is also necessary that each participant enter into dialogue not only with his partner across the faith line-the Lutheran with the Anglican, for example-but also with his coreligionists, with his fellow Lutherans, to share with them the fruits of the interreligious dialogue. Only thus can the whole community eventually learn and change, moving toward an ever more perceptive insight into reality.

THIRD COMMANDMENT: Each participant must come to the dialogue with complete honesty and sincerity. It should be made clear in what direction the major and minor thrusts of the tradition move, what the future shifts might be, and, if necessary, where the participant has difficulties with her own tradition. No false fronts have any place in dialogue.

FOURTH COMMANDMENT: Each participant must assume a similar complete honesty and sincerity in the other partners. Not only will the absence of sincerity prevent dialogue from happening, but the absence of the assumption of the partners' sincerity will do so as well. In brief: no trust, no dialogue.

FIFTH COMMANDMENT: Each participant must define himself. Only the Jew, for example, can define from the inside what it means to be a Jew. The rest can only describe what it looks like from the outside. Moreover, because dialogue is a dynamic medium, as each participant learns, he will change and hence continually deepen, expand, and modify his self-definition as a Jew - being careful to remain in constant dialogue with fellow Jews. Thus it is mandatory that each dialogue partner define what it means to be an authentic member of his own tradition.

Conversely-the one interpreted must be able to recognize herself in the interpretation. This is the golden rule of interreligious hermeneutics, as has been often reiterated by the "apostle of interreligious dialogue," Raimundo Panikkar. For the sake of understanding, each dialogue participant will naturally attempt to express for herself what 
she thinks is the meaning of the partner's statement; the partner must be able to recognize herself in that expression. The advocate of "a world theology," Wilfred Cantwell Smith, would add that the expression must also be verifiable by critical observers who are not involved.

SIXTH COMMANDMENT: Each participant must come to the dialogue with no hard-and-fast assumptions as to where the points of disagreement are. Rather, each partner should not only listen to the other partner with openness and sympathy but also attempt to agree with the dialogue partner as far as is possible while still maintaining integrity with his own tradition; where he absolutely can agree no further without violating his own integrity, precisely there is the real point of disagreement-which most often turns out to be different from the point of disagreement that was falsely assumed ahead of time.

SEVENTH COMMANDMENT: Dialogue can take place only between equals or par cum pari as Vatican II put it. This means that not only can there be no dialogue between a skilled scholar and a "person in the pew" type (at most there can only be a garnering of data in the manner of an interrogation), but also there can be no such thing as a one-way dialogue. For example, Jewish-Christian discussions begun in the 1960's were mainly only prolegomena to interreligious dialogue. Understandably and properly, the Jews came to these exchanges only to teach the Christians, although the Christians came mainly to learn. But, if authentic interreligious dialogue between Christians and Jews is to occur, then the Jews must also come mainly to learn; only then will it be par cum pari.

EIGHTH COMMANDMENT: Dialogue can take place only on the basis of mutual trust. Although interreligious dialogue must occur with some kind of "corporate" dimension, that is, the participants must be involved as members of a religious community-for instance, qua Buddhists or Hindus-it is also fundamentally true that it is only persons who can enter into dialogue. But a dialogue among persons can be built only on personal trust. Hence it is wise not to tackle the most difficult problems in the beginning, but rather to approach first those issues most likely to provide some common ground, thereby establishing the basis of human trust. Then, gradually, as this personal trust deepens and expands, the more thorny matters can be undertaken. Thus, as in learning we move from the known to the unknown, so in dialogue we proceed from commonly held matters-which, given our mutual ignorance resulting from centuries of hostility, will take us quite some time to discover fully-to discuss matters of disagreement.

NINTH COMMANDMENT: Persons entering into interreligious dialogue must be at least minimally self-critical of both themselves and their own religious traditions. A lack of such self-criticism implies that one's own tradition already has all the correct answers. Such an attitude 
makes dialogue not only unnecessary, but even impossible, since we enter into dialogue primarily so we can learn-which obviously is impossible if our tradition has never made a misstep, if it has all the right answers. To be sure, in interreligious dialogue one must stand within a religious tradition with integrity and conviction, but such integrity and conviction must include, not exclude, a health self-criticism. Without it there can be no dialogue - and, indeed, no integrity.

TENTH COMMANDMENT: Each participant eventually must attempt to experience the partner's religion "from within"; for a religion is not merely something of the head, but also of the spirit, heart, and "whole being," individual and communal. John Dunne here speaks of "passing over" into another's religious experience and then coming back enlightened, broadened, and deepened.

Interreligious dialogue operates in three areas: the practical, where we collaborate to help humanity; the cognitive, where we seek understanding and truth; and the "spiritual" where we attempt to experience the partner's religion "from within." Interreligious dialogue also has three phases. In the first phase we unlearn misinformation about each other and begin to know each other as we truly are. In phase two we begin to discern values in the partner's tradition and wish to appropriate them into our own tradition. For example, in the Catholic-Protestant dialogue, Catholics have learned to stress the Bible, and Protestants have learned to appreciate the sacramental approach to Christian life-both values traditionally associated with the other's religious community. If we are serious, persistent, and sensitive enough in the dialogue, we may at times enter into phase three. Here we together begin to explore new areas of reality, of meaning, and of truth, of which neither of us had even been aware before. We are brought face to face with this new, as-yetunknown-to-us dimension of reality only because of questions, insights, probings produced in the dialogue. We may thus dare to say that patiently pursued dialogue can become an instrument of new "revelation," a further "un-veiling" of reality—on which we must then act.

-LEONARD SWIDLER 